\title{
Integrated hydrogeological modelling of hard-rock semi-arid terrain: supporting sustainable agricultural groundwater use in Hout catchment, Limpopo Province, South Africa
}

\author{
Girma Y. Ebrahim ${ }^{1}$ - Karen G. Villholth ${ }^{1} \cdot$ Maurice Boulos ${ }^{1,2}$
}

Received: 21 April 2018 / Accepted: 23 February 2019 / Published online: 27 March 2019

(C) The Author(s) 2019

\begin{abstract}
An integrated hydrogeological modelling approach applicable to hard-rock aquifers in semi-arid data-scarce Africa was developed using remote sensing, rainfall-runoff modelling, and a three-dimensional (3D) dynamic model. The integrated modelling approach was applied to the Hout catchment, Limpopo Province, South Africa, an important agricultural region where groundwater abstraction for irrigation doubled during 1968-1986. Since the 1960s, groundwater levels in irrigated areas have displayed extended periods of decline with partial or full recovery in response to major decadal rainfall events or periods. The integrated dynamic 3D hydrogeological flow model, based on the One-Water Hydrologic Flow Model (MODFLOW-OWHM), helped to understand recharge and flow processes and inform water use and management. Irrigation abstraction was estimated based on irrigated crop area delineated using the Landsat Normalized Difference Vegetation Index (NDVI) and crop water requirements. Using groundwater level data, the model was calibrated (2008-2012) and validated (2013-2015). Estimated mean diffuse recharge $(3.3 \pm 2.5 \%$ of annual rainfall) compared well with estimates from the Precipitation Runoff Modelling System model. Recharge and groundwater storage showed significant inter-annual variability. The ephemeral river was found to be losing, with mean net flux to the aquifer (focused recharge) of $\sim 1.1 \%$ of annual rainfall. The results indicate a delicate human-natural system reliant on the small but highly variable recharge, propagating through variable pumping to an even more variable storage, making the combined system vulnerable to climate and anthropogenic changes. The integrated modelling is fundamental for understanding spatio-temporal variability in key parameters required for managing the groundwater resource sustainably.
\end{abstract}

Keywords Groundwater recharge $\cdot$ Hard rock aquifers $\cdot$ Integrated hydrogeological modelling $\cdot$ South Africa $\cdot$ Sub-Saharan Africa

\section{Introduction}

Integrated hydrogeological models consider feedback processes that affect the timing and rate of evapotranspiration, surface runoff, unsaturated flow and groundwater interactions (Markstrom et al. 2008). Unlike classical groundwater

Electronic supplementary material The online version of this article (https://doi.org/10.1007/s10040-019-01957-6) contains supplementary material, which is available to authorized users.

Girma Y. Ebrahim

g.ebrahim@cgiar.org

1 International Water Management Institute, 141 Creswell Road Weavind Park, Silverton, Pretoria, South Africa

2 Swiss Federal Institute of Technology Zurich, Zurich, Switzerland models, which require external estimation of recharge and evapotranspiration fluxes, integrated hydrogeological models use internal modules to calculate these fluxes and link them to the groundwater system (Xu et al. 2012). They are useful to develop conjunctive surface/groundwater-resource-management plans and test water management scenarios that take into account complex interactions of the hydrological system, particularly in a changing climate. According to the NGWA (2017) inventory, integrated hydrogeological models can be grouped into three categories depending on the governing equation used for simulating saturated and unsaturated flows and the level of integrations across sub-systems: (1) fully integrated models (e.g. MIKE SHE; Abbott et al. 1986a, 1986b) — that simultaneously solve the governing equation of surface water (i.e., the Saint Venant equation, which describes unsteady flow on the land surface) and groundwater flow (i.e., the Richards equation, which 
describes unsteady flow through a variably saturated porous medium), (2) automatically coupled models, which simulate separate regions of the hydrologic and hydrogeological systems and integrate them through boundary condition links using an iterative matrix solution method (e.g., GSFLOW; Markstrom et al. 2008), and (3) manually coupled models, which use separate surface and groundwater models set up independently and are calibrated to common observation data (e.g., SWAT-MODFLOW; Sophocleous and Perkins 2000; Kim et al. 2008). Model selection depends on knowledge of the natural system, model functionality matching to the water resource problem being solved, available data, and computational requirements (Dogrul et al. 2016).

In support of sustainable groundwater use in irrigated agriculture, integrated hydrogeological models of varying complexity have been applied worldwide. Shu et al. (2012) and Qin et al. (2013) applied MIKE SHE to analyse the water balance components and to assess water management options in the North China Plains. Faunt (2009) and Hanson et al. (2014a, 2015) applied the MODFLOW-based OneWater Hydrologic Flow Model (MODFLOW-OWHM) to assess groundwater availability in three different case studies in California. Bushira et al. (2017) used MODFLOW-OWHM to assess surface-water/groundwater interactions and dynamics in the Colorado River Delta aquifer in Mexico, while Hassan et al. (2014) used GSFLOW to assess surface watergroundwater interactions in a hard rock aquifer of the Sardon Catchment, western Spain.

Hard rock aquifers, which are generally hydrogeologically complex and less prolific due to their relatively limited or highly heterogeneous water storage and yields (Dewandel et al. 2006), are particularly prevalent in semi-arid and arid areas (Maréchal et al. 2004; MacDonald et al. 2009) and are often the primary water source for large populations (Titus et al. 2009). This indicates that these aquifer types are vulnerable to drought and overexploitation (Villholth et al. 2013) and hence critical to understand and to model in order to support water security, resilience and sustainable groundwater management (Ahmed et al. 2008). However, integrated catchment-scale assessments in these settings, where the temporal-spatial variation of recharge is determined as an integral aspect of the modelling, are presently relatively rare (Ahmed et al. 2008).

Agriculture in the Hout catchment, Limpopo Province, South Africa, is heavily dependent on groundwater for irrigation and other uses because surface water is limited or intermittent. There was a doubling in groundwater abstraction for irrigation from $9.0 \times 10^{6}$ to $21 \times 10^{6} \mathrm{~m}^{3} /$ year from 1968 to 1986 (Jolly 1986). Groundwater is also used for domestic supply and livestock; however, groundwater abstraction in the area has been reported by FAO (2004) to exceed average recharge over multiple years and leading to unsustainable development. Therefore, with increasing demand for food, and climate change potentially affecting recharge as well as water demand, sustainable management of groundwater resources is becoming increasingly important for sustainable food production and economic development in the area. This requires better understanding of the groundwater dynamics, the water balance and trends therein.

The main aim of this study was to develop an integrated hydrogeological modelling approach to support guidance on groundwater and agricultural water management solutions in semi-arid hard rock terrain, using the Hout catchment as a case study. A combined approach, which allows the utilization of remote sensing and rainfall-runoff modelling in $3 \mathrm{D}$ hydrogeological modelling was developed to overcome lack of data (e.g. on groundwater abstraction) in a data scarce setting. Gaps in understanding and modelling capability were identified. Finally, the model was applied to understand the relative magnitude of abstraction licenses relative to actual (simulated) abstractions.

\section{Study area}

The Hout catchment is located $60 \mathrm{~km}$ northwest of Polokwane city (Fig. 1) and has an area of $2,478 \mathrm{~km}^{2}$. The catchment area is divided into three quaternary (fourth-order) catchments (A71E, A71F, and A71G). Catchment elevation ranges from 840 to $1,739 \mathrm{~m}$ above mean sea level (mamsl). Hout River is a tributary to the Sand River, which drains into the Limpopo River. Hout River is an ephemeral river that flows intermittently following large and intense precipitation events during the wet season. The Hout River Dam is the only large dam on the Hout River. The climate is semi-arid, with an annual long-term mean precipitation of $407 \mathrm{~mm} / \mathrm{year}$ (Dendron climate station, 1972-2015). The soil type is sandy, and Luvisols cover about $56 \%$ of the area-see section S1, Fig. S1 and Table $\mathrm{S} 1$ of the electronic supplementary material (ESM). The area is known for its potato production (van der Waals et al. 2004). Centre pivot is the main irrigation system used. Natural vegetation and agricultural land (including irrigated and nonirrigated fields) cover about 63 and $25 \%$ of the catchment area, respectively (Fig. 2a and Table 1). The geology is characterized by the crystalline basement complex of the Hout River Gneiss (loosely defined as 'hard rock') throughout the catchment (Holland 2011). Nearly vertical dolerite dikes intrude across the subsurface, and secondary fractures formed by and adjacent to dike intrusion constitute higher permeability zones, which have been targeted for groundwater development in similar geology all over South Africa (du Toit 2001). According to Jolly (1986), the study area consists of two aquifers: a weathered gneiss aquifer (12$50 \mathrm{~m}$ below the ground) and a fractured gneiss aquifer below the weathered zone that extends up to $120 \mathrm{~m}$ below the ground, whereby the fractured lower aquifer is known as high 


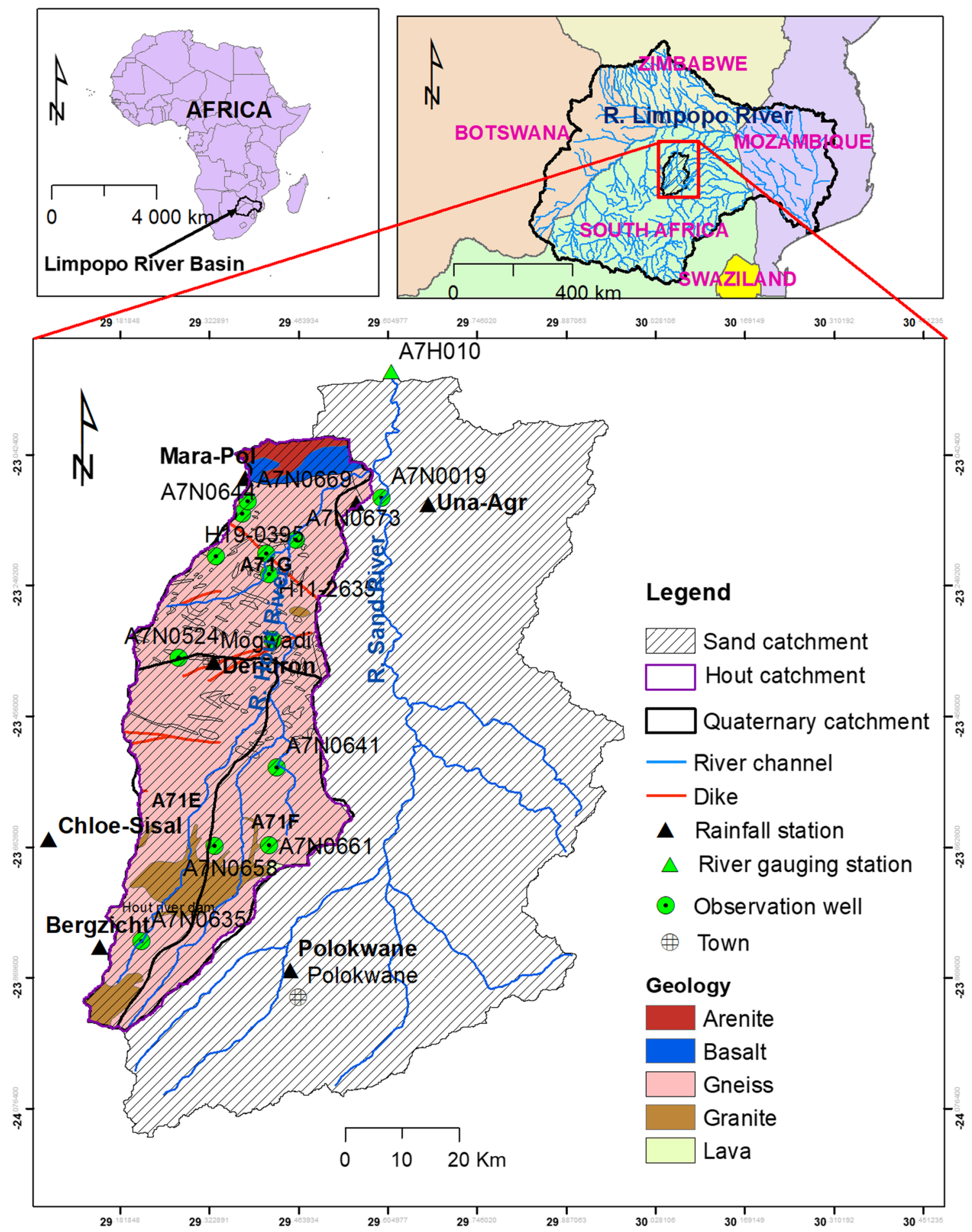

Fig. 1 Location of Hout and Sand catchments within the larger Limpopo River basin (indicated in Africa map). Geology (1:1 million scale) obtained from Council for Geoscience. Observation points are indicated

yielding due to fractures collecting water, and the upper weathered aquifer is low-yielding (Jolly 1986). In most cases, the water table is deeper than the weathered zone (Holland 2012); hence, and due to higher yields, the deep aquifer represents the zone screened by most production wells in the area (Holland 2011, 2012).

\section{Methodology}

Application of a hydrogeological model for better understanding and management of the groundwater resources in the Hout catchment was recommended long ago (Vegter 2003). The groundwater flow system was modelled with MODFLOW- 


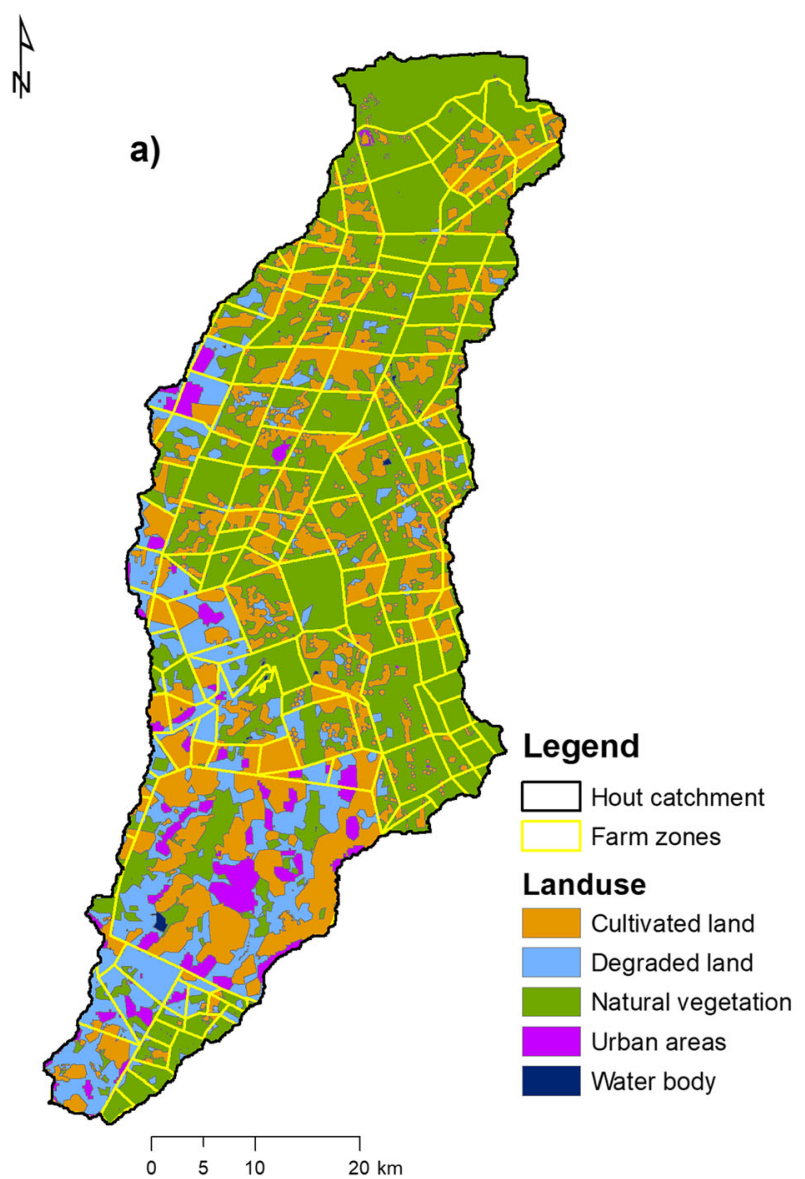

Fig. 2 a Land use/land cover of the Hout catchment (extracted from 2009 National mosaic landcover map produced by South African National Biodiversity institute (SANBI), and farm zones based on land ownership

OWHM (Hanson et al. 2014b) using the ModelMuse graphic user interface (Winston 2009). To constrain the simulated runoff by MODFLOW-OWHM, a rainfall-runoff model was developed for the combined Hout and Sand catchments using the Precipitation Runoff Modelling System (PRMS) and calibrated with streamflow measured at the outlet of the Sand catchment (A7H010 gauging station, Fig. 1). This was done because there is no river gauging station in the Hout catchment.

Table 1 Percentage of area covered by different land use/land cover types

\begin{tabular}{lll}
\hline Land use/land cover type & Area $\left(\mathrm{km}^{2}\right)$ & $\begin{array}{l}\% \text { area covered by } \\
\text { land use type }\end{array}$ \\
\hline Cultivated land & 628.07 & 25.33 \\
Degraded land & 543.04 & 21.91 \\
Natural vegetation & $1,240.50$ & 50.05 \\
Urban areas & 63.68 & 2.57 \\
Water body & 3.42 & 0.14 \\
\hline
\end{tabular}

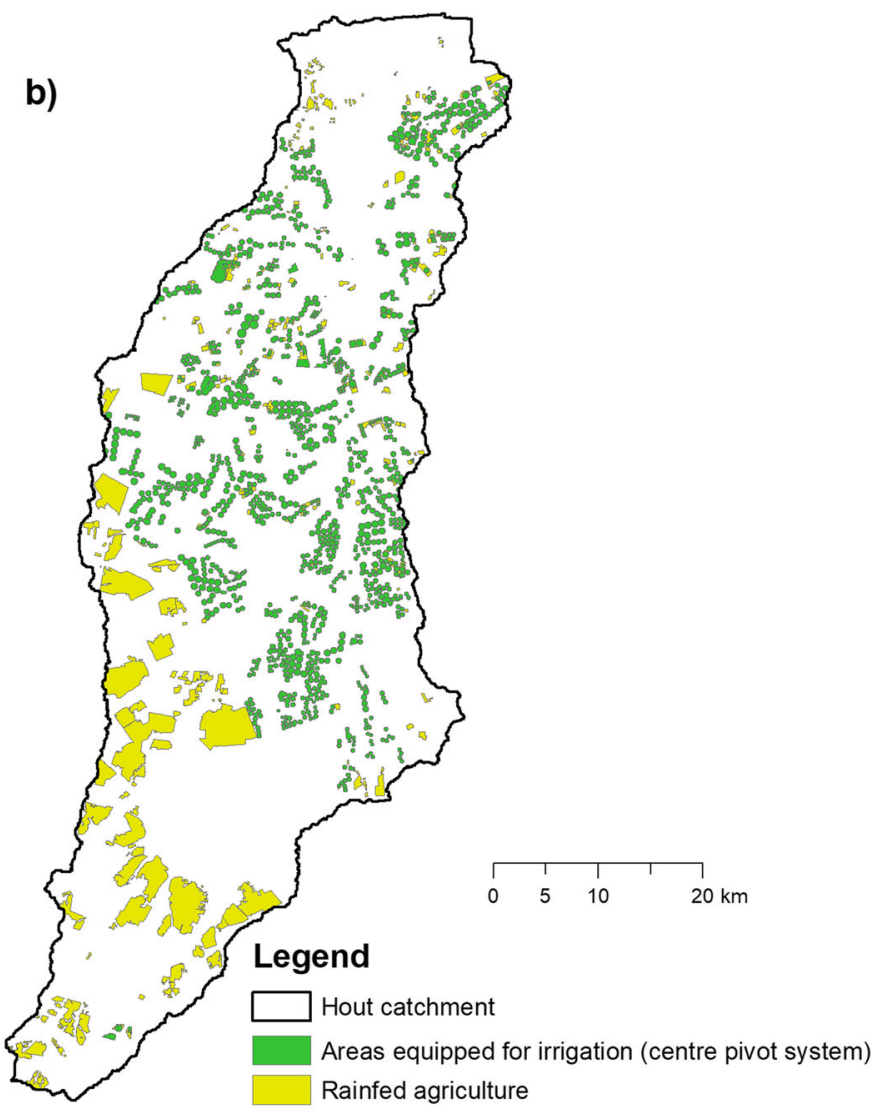

digitized from 1:50,000 topographic sheet. b Potentially irrigated and rainfed agricultural areas (Source: The National Department of Agriculture Forestry and Fisheries of South Africa)

Groundwater flow in the fractured rock aquifer, as well as in the weathered region, was simulated assuming an equivalent porous medium (EPM) approach (Long et al. 1982), where fractures are assumed to form a network of interconnected conduits analogous to a continuous pore space within a granular medium (Kaehler and Hsieh 1994). This assumption is valid where fractures are prolific, and fracture openings are relatively small compared to the rock volume containing the fractures, and these openings are interconnected (Tiedeman et al. 2003). The EPM approach has been successfully applied in fractured rock aquifers (Tiedeman et al. 2003; Varalakshmi et al. 2012; Hassan et al. 2014) and in highly heterogeneous karst aquifers (Larocque et al. 1999; Scanlon et al. 2003; Ghasemizadeh et al. 2015).

\section{Hydrogeological model description}

MODFLOW-OWHM is an integrated hydrogeological model, designed for analysing combined processes and use of groundwater, unsaturated zone and surface water processes of the hydrological cycle for irrigated and nonirrigated areas. The model was originally developed in response to a general 
need for improved estimation of water budgets in irrigated agricultural areas and conjunctive use of groundwater and surface water supplies (Hanson et al. 2010). The finite difference MODFLOW-OWHM consists of the Farm Process package, version 3 (FMP3) (Schmid and Hanson 2009) integrated into the MODFLOW 2005 model, which includes the threedimensional (3D) saturated flow, based on Darcy's equation (Harbaugh 2005). MODFLOW-OWHM also includes primary packages such as the Streamflow Routing and River package to simulate surface-water/groundwater interaction in rivers and streams, the Unsaturated-Zone Flow (UZF1) package to simulate water flow and storage in the unsaturated zone, and the Horizontal Flow Barrier (HFB) package to simulate barriers to flow such as dikes. In the present model, the riveraquifer interaction was represented using the Streamflow Routing (SFR2) package (Niswonger and Prudic 2005). The HFB package was also applied; however, the unsaturated zone processes below the root zone were not modelled; hence, direct recharge out of the root zone, which was simulated as part of the Farm Process package, was assumed.

MODFLOW-OWHM simulates evaporation and transpiration components based on precipitation, irrigation, and groundwater levels on a cell-by-cell basis within userdefined water balance regions or farm zones (Hanson et al. 2010). The core concept of the model is to internally calculate crop irrigation requirement and allocate surface and/or groundwater irrigation supplies to meet those demands that cannot be met by precipitation and root uptake directly from groundwater. MODFLOW-OWHM does not simulate soilmoisture storage change in the root zone. The model applies a steady-state soil-moisture assumption for the root zone, of which the appropriateness has been tested with a HYDRUS2D soil-column simulation representing shallow-tomedium-depth root zone for irrigated soil, and has been found to be valid for longer time steps, on the order of weeks or longer (Schmid et al. 2006). All inflow into the root zone is assumed to be in balance with outflows from the root zone for each time step; although, in reality, the root zone is part of the unsaturated zone, in MODFLOW-OWHM, the root zone is conceptualized separately from the unsaturated zone. When the optional UZF1 package (Niswonger et al. 2006) is used with FMP package, recharge leaving the root zone is passed to the UZF1 package as infiltration. The UZF1 package then simulates unsaturated zone processes below the rootzone such as exfiltration when the infiltration rate exceeds the hydraulic conductivity of the unsaturated zone, rejected infiltration in the riparian areas (due to high groundwater levels), and delayed recharge beneath the root zone. Evapotranspiration should not be simulated in the UZF1 package when used with FMP package; otherwise, there could be a double accounting of evapotranspiration. If UZF1 is not activated, recharge from the root zone passes directly to the uppermost active aquifer layer.
Crop consumptive use - actual evapotranspiration (ET) which includes both crop transpiration and evaporation in all land use types is calculated using Eq. (1). To simplify calculations, transpiration and evaporation per grid cell were assumed to occur in vegetated and nonvegetated areas of each land use type, respectively. To represent the crop transpiration and soil evaporation process separately, the model applied two user-defined time-variable parameters, a transpiration fraction $\left(k_{\mathrm{T}}\right)$ and an evaporation fraction $\left(k_{\mathrm{E}}\right)$ to represent relative fractions of the evapotranspiration within a given land use type. Transpiration (T) from vegetated area was calculated using Eq. (2) and the evaporation $(E)$ from nonvegetated area within a given land use type was calculated using Eqs. (3) and (4). The transpiration fraction was assumed independent of whether the crop evapotranspiration is satisfied by irrigation, precipitation, or groundwater uptake. Evaporation from nonvegetated area, on the other hand, was calculated differently for precipitation and irrigation as a source, as it depends on wetted area. Evaporation from precipitation was assumed to occur over the entire nonvegetated area exposed to water input, because all nonvegetated area will be wetted, such that the fraction of evaporation from precipitation is $k_{\mathrm{E}}^{\mathrm{P}}=1-k_{\mathrm{T}}$. Unlike the soil surface wetted by precipitation, the exposed areas wetted by irrigation may not be entirely wetted. In this case, the evaporation fraction from irrigation is $k_{\mathrm{E}}^{\mathrm{i}}<1-k_{\mathrm{T}}$. The extent to which the exposed area is wetted depends on the irrigation method. For example, for irrigation methods like basin flooding irrigation, a complete inundation of the nonvegetated area is expected, and thus $k_{\mathrm{E}}^{i}=1-k_{\mathrm{T}}$, while for e.g. centre pivot, irrigation, $k_{\mathrm{E}}^{\mathrm{i}}<1-k_{\mathrm{T}}$. The partitioning of evapotranspiration into soil evaporation and crop transpiration is dependent on the growth stage of the crop. During crop emergence, soil evaporation predominates (at sowing, nearly $100 \%$ of ET comes from evaporation $\left(k_{\mathrm{T}}=0\right)$, but once the crop is well developed and completely covers the soil, transpiration becomes the main process (Allen et al. 1998)). The model used similar methodology previously described to estimate evapotranspiration for a wide variety of land uses, including natural vegetation, fallow fields, waterbodies and urban landscape settings, using adapted values for the coefficients mentioned in the preceding.

$\mathrm{ET}=\mathrm{kc} \times \mathrm{ET}_{\mathrm{o}}$

where ET is the actual evapotranspiration (m/day), kc is the seasonally dependent crop-specific coefficient $(-)$ and $\mathrm{ET}_{\mathrm{O}}$ is the potential evapotranspiration rate ( $\mathrm{m} /$ day).

$$
\begin{aligned}
& T=k_{\mathrm{T}} \times \mathrm{ET}=k_{\mathrm{T}} \times \mathrm{kc} \times \mathrm{ET}_{\mathrm{o}} \\
& E_{\mathrm{P}}=k_{\mathrm{E}}^{\mathrm{P}} \times \mathrm{kc} \times \mathrm{ET}_{\mathrm{o}}=\left(1-k_{\mathrm{T}}\right) \times \mathrm{kc} \times \mathrm{ET}_{\mathrm{o}},
\end{aligned}
$$
when water source is precipitation

$E_{i}=k_{\mathrm{E}}^{\mathrm{i}} \times \mathrm{kc} \times \mathrm{ET}_{\mathrm{o}}$, when water source is irrigation $\left(k_{\mathrm{E}}^{\mathrm{i}} \leq 1-k_{\mathrm{T}}\right)$ 
Surface runoff per grid cell was calculated as a sum of the excess irrigation and the excess precipitation (Eq. 5). The fractions of excess precipitation and excess irrigation that become surface runoff ( $\mathrm{IE}_{\mathrm{SWP}}$ and $\mathrm{IE}_{\mathrm{SWI}}$, respectively) were user-specified and depended on irrigation method. Depending on whether higher or lower intensity rainfall was dominating the stress period, $\mathrm{IE}_{\mathrm{SWP}}$ per land use could be specified either closer to 1.0 or 0.0 (Schmid 2004). For the current study, however, constant values for each land use type were used. Surface runoff was discharged directly to the nearest stream segment (no routing on the soil surface was considered) and routed through the channel system using SFR2 (section 'River-aquifer interactions').

Surface runoff $=(I-\mathrm{CIR}) \times \mathrm{IE}_{\mathrm{SWI}}+\left(P-\mathrm{ET}_{\mathrm{P}}\right) \times \mathrm{IE}_{\mathrm{SWP}}(5)$

$\begin{array}{ll}I & \text { Applied irrigation (m/day) } \\ P & \begin{array}{l}\text { Precipitation (m/day) } \\ \text { Actual evaporation and transpiration from } \\ \mathrm{ET}_{\mathrm{P}}\end{array} \\ \mathrm{IE}_{\mathrm{SWI}} & \begin{array}{l}\text { precipitation (m/day) } \\ \text { Fraction of excess irrigation that becomes surface } \\ \text { runoff }(-)\end{array} \\ \mathrm{IE}_{\mathrm{SWP}} & \begin{array}{l}\text { Fraction of excess precipitation that becomes surface } \\ \text { runoff }(-)\end{array}\end{array}$

Under standard nongroundwater-influenced crop conditions, $\mathrm{ET}_{\mathrm{P}}$ is calculated using Eqs. (6) and (7). In the case of Eq. (6), the supply from precipitation needs to be supplemented by irrigation in order to satisfy the necessary crop transpiration requirements.

$$
\begin{array}{ll}
\mathrm{ET}_{\mathrm{P}}=\left(k_{\mathrm{T}} \times P\right)+k_{\mathrm{E}}^{\mathrm{P}} \times P & P \leq \mathrm{ET}_{\mathrm{o}} \\
\mathrm{ET}_{\mathrm{P}}=\left(k_{\mathrm{T}} \times \mathrm{ET}_{\mathrm{o}}\right)+k_{\mathrm{E}}^{\mathrm{P}} \times \mathrm{ET}_{\mathrm{o}} & P>\mathrm{ET}_{\mathrm{o}}
\end{array}
$$

Net groundwater recharge $\left(R_{\mathrm{n}}\right)$ was calculated as the sum of percolation below the root zone arising from excess precipitation $\left(P-\mathrm{ET}_{\mathrm{P}}\right)$ and excess irrigation $(I-\mathrm{CIR})$ minus surface runoff and direct evapotranspiration from groundwater (ET $\mathrm{GW}_{\text {; }}$ Eq. 8).

$$
\begin{aligned}
R_{\mathrm{n}}= & (I-\mathrm{CIR}) \times\left(1-\mathrm{IE}_{\mathrm{SWI}}\right)+\left(P-\mathrm{ET}_{\mathrm{P}}\right) \\
& \times\left(1-\mathrm{IE}_{\mathrm{SWP}}\right)-\mathrm{ET}_{\mathrm{GW}}
\end{aligned}
$$

Direct evapotranspiration from groundwater was calculated as a lumped value of separate evaporation and transpiration from groundwater in vegetated and nonvegetated areas per grid cell. The extinction depth for transpiration from groundwater was assumed to be the ground surface minus root depth minus thickness of the capillary fringe, while for evaporation from groundwater, it was assumed to be ground surface minus thickness of the capillary fringe (section S2 of the ESM). Transpiration from groundwater was assumed to increase from zero when the water table rises above the transpiration extinction depth and reach maximum when the water table is at the root zone depth, then decrease again to zero when the groundwater level rises to ground surface to account for transpiration restriction due to lack of aeration. The evaporation from groundwater over exposed noncropped areas was assumed to decrease linearly from maximum evaporation when the highest point of the capillary fringe is at the ground surface to zero at the evaporation extinction depth (Schmid et al. 2006).

Crop irrigation requirements (CIR) were calculated as a sum of transpiratory and evaporative crop irrigation requirements (Eq. 9). The transpiration requirement from irrigation $\left(T_{\mathrm{i}}\right)$ is equal to actual (assumed the optimal) crop transpiration $\left(T_{\text {c-act }}\right)$ minus actual crop transpiration satisfied by precipitation $\left(T_{\mathrm{p} \text {-act }}\right)$ minus actual transpiration from groundwater by root uptake $\left(T_{\mathrm{gw}-a c t}\right)$. The evaporation requirement from irrigation $\left(E_{\mathrm{i}}\right)$ was assumed to vary proportionally to transpiration, and equality between $E_{\mathrm{i}} / T_{\mathrm{i}}$ and $k_{\mathrm{E}}^{\mathrm{i}} / k_{\mathrm{T}}$ was assumed (Schmid et al. 2006); hence, $E_{\mathrm{i}}=T_{\mathrm{i}} \times k_{\mathrm{E}}^{\mathrm{i}} / k_{\mathrm{T}}$.

$\mathrm{CIR}=T_{\mathrm{i}}+E_{\mathrm{i}}=\left(T_{\mathrm{c}-\mathrm{act}}-T_{\mathrm{P}-\mathrm{act}}-T_{\mathrm{gw}-\mathrm{act}}\right) \times\left(1+\frac{k_{\mathrm{E}}^{\mathrm{i}}}{k_{\mathrm{T}}}\right)$

\section{Hydrogeological model setup}

\section{Conceptual model}

The active model domain covers the Hout catchment $\left(2,478 \mathrm{~km}^{2}\right)$. The lateral model boundaries are coincident with the watershed divide determined by surface-water runoff. Holland and Witthüser (2011) presented a conceptual hydrogeological model of the area. A generalized 3D geological and hydrogeological conceptual model for crystalline aquifers can be found in Ahmed (2008) and Dewandel et al. (2006). Geologically, the aquifer system includes the weathered zone above the fractured rock (Jolly 1986). According to Jolly (1986), the weathered aquifer is unconfined to semi-confined, and the fractured rock aquifer is confined.

The aquifer is dissected by dikes; however, the role of dikes in relation to the groundwater flow in the area is largely unknown. Based on pumping tests in a cave sandstone aquifer in Botswana, Morel and Wikramaratna (1982) reported that the transmissivity of dolerite dikes is at least a hundred times smaller than the transmissivity for a cave sandstone aquifer. Another study in Botswana, by Bromley et al. (1994), found that dolerite dikes less than $10 \mathrm{~m}$ in thickness tend to be permeable due to cooling joints and fractures that generate hydraulic continuity across the intrusion, whereas thicker dolerite dikes serve as groundwater barriers. In the present study, dikes were assumed to constrain flow and modelled using the HFB package (Hsieh and Freckleton 1993), as demonstrated 
in Faunt et al. (2004). The dikes were assumed to be vertical, extend throughout the formation, and protrude to the surface of the ground. Dikes shown in Fig. 1 were included in the model. In HFB, the dikes were conceptualized as being located in the boundary between two adjacent finite difference cells. HFB reduces the horizontal hydraulic conductance of the two cells adjacent to the dike equally to account for the barriers. The HFB package allows the capability to use the dike hydraulic characteristic (Dike hydr $_{\text {is }}$ hydraulic conductivity of the dike divided by the thickness of the dike) as a calibration parameter.

The mechanisms for recharge to the aquifer considered were diffuse recharge from precipitation, irrigation return flows from irrigated areas, and focused recharge from the river. Net discharge from the catchment occurs through evapotranspiration, lateral groundwater outflow, groundwater pumping (domestic and stock watering), and streamflow.

\section{Model discretization}

The model domain was discretized into 1,036 rows and 482 columns (499,352 cells) with a uniform grid size of $100 \mathrm{~m} \times$ $100 \mathrm{~m}$. The model was divided vertically into two layers; the top layer representing the weathered zone, and the bottom layer representing the fractured rock aquifer. The Hout River Gneiss covers about $82 \%$ of the study area, and there is no distinct difference in geology; hence, spatially individually homogenous layers were assumed. The upper layer was represented in the model as an unconfined aquifer, while the bottom layer was treated as a convertible layer, to allow switch between confined and unconfined conditions when the upper layer becomes dry or rewets. The top elevation of the upper layer was determined from the $20 \mathrm{~m} \times 20 \mathrm{~m}$ digital elevation model obtained from Riskscape (2017). Weathering depth was determined from interpolated (kriging) lithological well log data from the National Groundwater Archive (NGA; section S3 and Fig. S3 of the ESM). Based on interpolated weathering depth and an assumed uniform total aquifer thickness of $120 \mathrm{~m}$ (Jolly 1986), spatially variable thickness was defined for the fractured aquifer layer as the difference. The 9-year simulation period (2007-2015) was divided into 108 monthly stress periods. Each stress period, within which all model inputs on stresses like climate remained constant, was further divided into bimonthly computational time steps; hence, time series data input, like rainfall, was on a monthly basis.

\section{Boundary and initial conditions}

An impermeable watershed boundary was assumed along all sides of the model except for a 6-km stretch along the catchment outlet (Fig. S4 of the ESM), which is justified by the piezometric surface generated from observed spatially interpolated hydraulic heads. Holland (2011) also reported that groundwater flow in the area generally follows topography. A general head boundary (GHB) was specified at the catchment outlet based on observed water level data at monitoring well A7N0019 after correcting for elevation difference and water level gradient (section S5 and Fig. S4 of the ESM). The model was assumed impervious at the bottom, $120 \mathrm{~m}$ below the ground surface. Initial conditions were defined based on interpolated (using kriging) observed water level data for the period of 2005-2007 (section S4 and Fig. S4 of the ESM). To further smooth out the initial interpolated surface, a transient model for year 2007 was run repeatedly six times to establish dynamic equilibrium as demonstrated by Barlow and Dickerman (2001).

\section{Groundwater pumping}

Domestic and stock watering pumping Abstraction for municipal and domestic supply was specified based on reported and estimated values. The annual total domestic abstraction from groundwater for the three quaternary catchments was obtained from Lombaard et al. (2015) and was $4.1 \times 10^{6} \mathrm{~m}^{3} /$ year $\left(11,233 \mathrm{~m}^{3} /\right.$ day $)$. The total volume was distributed evenly in time across 106 existing domestic wells identified from NGA. Similarly, livestock water requirements were estimated using data on licensed stock watering wells from the Department of Water and Sanitation (DWS). The total registered licensed volume for 14 licensed livestock watering wells was $109,724 \mathrm{~m}^{3} /$ year $\left(300 \mathrm{~m}^{3} /\right.$ day). In general, groundwater pumping for domestic and stock watering was small compared to irrigation pumping.

Irrigation pumping Groundwater abstraction in irrigated fields was estimated indirectly from crop consumptive use (ET). The actually irrigated fields were delineated seasonally using remotely sensed data. The total irrigation water requirement represents the amount of water necessary for a particular crop's consumptive use under ideal conditions and associated irrigation losses. Since all irrigated agriculture in the study area was supplied by groundwater, no surface-water delivery was assumed. The estimation of irrigation abstraction in the model consisted of the following five steps.

1. Determining crop evapotranspiration (ET) requirement for actually irrigated areas per farm zone. The study area was divided into 193 farm zones based on landownership. These include all areas: irrigated and nonirrigated cropland, urban areas, and areas of natural vegetation (Fig. 2a).

2. Calculating the net crop irrigation requirement by subtracting from ET the part satisfied by precipitation and groundwater uptake by deep-rooted plants.

3. Calculating total crop irrigation requirements by dividing the net crop irrigation requirement by an on-farm irrigation efficiency. 
4. Determining crop irrigation pumping volume by multiplying the total irrigation water requirements by actually irrigated area per farm zone.

5. Determining the irrigation abstraction per well per farm zone by dividing the total irrigation pumping volume per farm zone by the number of existing irrigation wells in each farm. The locations of existing irrigation wells were obtained from NGA.

$\mathrm{ET}_{\mathrm{o}}$ rates used as time series input were determined using the Hargreaves method (Hargreaves and Samani 1985) based on temperature data from Polokwane meteorological station. Monthly rainfall input data were calculated from daily rainfall data from six rainfall stations within or close to the catchment (Fig. 1) obtained from the South African Weather Service. The Thiessen polygon method was used to obtain spatially distributed rainfall values (section S5 and Fig. S5 of the ESM). Thickness of the capillary fringe varies inversely with the pore size of the soil material and was determined from Hanson et al. (2015) to be $1.3 \mathrm{~m}$, assuming sandy loam.

Land use in the area was divided into five classes consisting of cultivated areas, degraded land, natural vegetation, urban built-up areas, and water bodies (Fig. 2a). Figure $2 \mathrm{a}$ also indicates the delineation of farm zones. Table 1 presents the percentage area of each land use type. The cultivated areas were further divided into irrigated areas and nonirrigated areas (or rather equipped or not equipped for irrigation). Areas equipped with irrigation, which are potentially irrigated, and rainfed agricultural areas are shown in Fig. $2 \mathrm{~b}$. The area equipped for irrigation is about $9 \%$ of the catchment area. The nonirrigated cultivated areas included rainfed agriculture or fallow areas. The land use/land cover map shown in Fig. 2a was used as a background map and overlaid with temporally varying actually irrigated areas delineated with the NDVI threshold method to identify which particular equipped areas were irrigated during each cropping season (section S7 of the ESM). Figure $2 b$ was used as a mask for delineating irrigated areas using the NDV threshold method. The irrigated crops were assumed to consist of potato exclusively. This simplification was introduced, because details of other minor (mostly vegetable crops) were not known, and because ET patterns would be similar.

The initial, mid, and end of season crop coefficients $(\mathrm{kc})$, as well as the duration for the initial, mid, and late growth stages for potato, were based on literature values (Allen et al. 1998; Hanson et al. 2015). The length of the full potato-cropping period was assumed to be 4.5 months. According to Franke et al. (2013), Limpopo Province experiences two main planting periods for potato, namely the early planting period, which goes from late February to March, and the main planting period, which starts in May and continues through the winter (dry season) till end of July, with June as peak planting month.
Due to the nonsymmetric spatial pattern in the planting and harvesting periods in the study area, and lack of detailed data, planting dates were assumed to be staggered uniformly from late February to end of July, and based on this assumption, composite $\mathrm{kc}$ values for each month of the year were calculated and applied uniformly across the irrigated fields. Figure S6 of the ESM shows kc values for potato as a single crop and the composite kc values over the calendar year for staggered cultivation; hence, each field was not distinctively specified with a kc curve, but rather the applicable composite $\mathrm{kc}$ values were applied if a field was identified as cropped in a particular season. A constant maximum root depth of $0.6 \mathrm{~m}$ for potato was used (DAFF 2013). The irrigation efficiency (only centre pivot) was set at 0.85 (New and Fipps 2000; Howell 2003). The transpiration fraction of consumptive use $\left(k_{\mathrm{T}}\right)$, the fraction of evaporation from precipitation $\left(k_{\mathrm{E}}^{\mathrm{P}}\right)$ and the fraction of evaporation from irrigation $\left(k_{\mathrm{E}}^{\mathrm{i}}\right)$ were determined for each land use type based on Hanson et al. (2015). The fraction of surface runoff from precipitation $\left(\mathrm{IE}_{\mathrm{SWP}}\right)$, assumed constant per land use type, was determined using initial manual model calibration by comparing surface runoff simulated by MODFLOW-OWHM against PRMS calibrated surface runoff. This value was then kept constant during the subsequent automatic calibration of the MOFLOW-OWHM for the Hout catchment. Estimated and calibrated parameter values are presented in Table S2 of the ESM.

To delineate areas actually irrigated, a method based on an NDVI threshold (section S8 of the ESM) was used (Pervez et al. 2014). First, to determine the period(s) of the year of maximum greenness in the area due to crop growth, moderate resolution imaging spectroradiometer (MODIS) NDVI maps were used as they have good temporal resolution (as often as days; Ozdogan et al. 2010). Mean monthly NDVI for areas equipped for irrigation were calculated based on MODIS 16 (every 16 days), and based on this, two crop growth (and irrigation) peak periods were identified: one in April and another in September (Fig. S7 of the ESM). Two Landsat images (one for each season) for every year were subsequently used to represent these two peak seasons and identify actually irrigated areas in each season (Table S3 of the ESM). Landsat was used because of the good spatial resolution (30 m). Each map (snapshot) was assumed representative of the corresponding season. The mean irrigated area delineated with the method during the simulation period for the dry (February-August) and wet periods (September-December) are 2,339 and 2,255 ha, respectively (Table S4 of the ESM). The coefficients of variation in irrigated area during the dry and wet period are 1.7 and $11.2 \%$, respectively. The mean actually irrigated area as percentage of area equipped for irrigation during the dry period is about $10.4 \%$, and for both dry and wet period is about $20.5 \%$ (Table S4 of the ESM). It should be noted that irrigated area delineation during the wet period was associated 
with larger uncertainties, because during this period, natural vegetation may have NDVI very similar to irrigated crops (section S7 of the ESM).

\section{River-aquifer interactions}

River-aquifer flux exchange was simulated using SFR2 (section S8 of the ESM). The Hout River channels were divided into five stream segments (Fig. S8 of the ESM) and the river channel cross-sections were assumed rectangular. Water added by precipitation directly on the stream channels and water removed by evapotranspiration directly from the stream channels were assumed to be negligible and disregarded. Surface runoff entering stream segments were calculated based on user-defined fractions $\left(\mathrm{IE}_{\mathrm{SWP}}\right.$ and $\left.\mathrm{IE}_{\mathrm{SWI}}\right)$ in the FMP package. For the purpose of parametrization, the stream segments were grouped into two, upstream (segments 1, 2, and 4; see Fig. S8 of the ESM) and downstream segments (3 and 5). Uniform vertical streambed hydraulic conductivities and Manning roughness coefficients were assigned for stream segments in the same group. The thickness of the streambed material was assumed to be $1 \mathrm{~m}$ for all segments. Streambed elevation and river channel cross-section was extracted from the digital elevation model. Initial calibration values for the Manning roughness coefficients were obtained from the literature (Arcement and Schneider 1989) and the final values were determined through model calibration together with the streambed hydraulic conductivity. Input parameters and data used in SFR2 are listed in Table S5 of the ESM.

\section{Rainfall-runoff modelling using the precipitation-runoff modelling system (PRMS)}

Independent streamflow and recharge estimations were carried out for the Hout and Sand catchments using the PRMS model, which is a distributed parameter rainfall-runoff model (Leavesley et al. 1983, 1995). Distributed parameter capabilities are provided by partitioning the watershed into hydrologically similar units, called hydrologic response units (HRUs). Each HRU is conceptualized as a parallel series of reservoirs representing an impervious surface zone, the root zone, the subsurface, and the groundwater, whose outflows combine to produce surface runoff (Fig. 3 and section S9 of the ESM). Since the Hout River is ungauged, PRMS modelling was carried out for the larger and gauged Sand River catchment $\left(7,731 \mathrm{~km}^{2}\right)$, encompassing the Hout sub-catchment, using river discharge data from the $\mathrm{A} 7 \mathrm{H} 010$ gauging station (Fig. 1). HRUs were delineated based on topography and this resulted in 59 HRUs (Fig. S9 of the ESM).

The PRMS model was applied using observed streamflow data 2003-2015. The model was run on a daily time step, but the calibration comparison was done using monthly streamflow data. Automated parameter calibration was carried out using the shuffled complex evolution (SCE) global search algorithm implemented in the LUCA (Let Us Calibrate) software (Hay et al. 2006), which contains a dedicated multipleobjective, stepwise automated procedure for PRMS calibration and an associated graphic user interface. The first year was used as a spin-up period, the data from 2004 to 2012 were used for model calibration, and data from 2013 to 2015 were used to validate the model.

\section{MODFLOW-OWHM calibration and validation}

The hydrogeological model for the Hout catchment was calibrated (2008-2012) and validated (2013-2015) using observed groundwater level data for 10 monitoring wells measured to various extent. Year 2007 was used as a spin-up period, subsequent to initial condition stabilisation, and no calibration was attempted during this period. Initial estimates of the aquifer system properties were made based on past studies in the study area (Jolly 1986; du Toit 2001; Holland 2011) and other literature for weathered-fractured aquifers (Rushton and Weller 1985; Maréchal et al. 2004; Ahmed et al. 2008). The mean hydraulic conductivity calculated from mean saturated thickness and transmissivity reported in Holland and Witthüser (2011) was $0.71 \mathrm{~m} /$ day. A hydraulic conductivity of $0.38 \mathrm{~m} /$ day (geometric mean) was reported in a weathered-fractured aquifer in India using slug tests (Maréchal et al. 2004). Pumping tests by Rushton and Weller (1985) conducted in a granite aquifer in India resulted in hydraulic conductivities of 3.0 and $5.0 \mathrm{~m} /$ day for the weathered and fractured rock aquifer, respectively. Specific yield and specific storage of $1 \times 10^{-2}$ and $2.5 \times 10^{-3}$ were reported by Rushton and Weller (1985) for the weathered and fractured zones, respectively, in India. The storage parameters from Rushton and Weller (1985) were directly used in Jolly (1986) for calculating groundwater storage in the Doringlaagte sub-catchment of the Hout catchment. Holland (2011) reported average storativity of $5 \times 10^{-2}$ for the Limpopo Plateau, which includes the study area. The values of vertical hydraulic conductivities were estimated to be an order of magnitude smaller than the corresponding horizontal hydraulic conductivity values, generating anisotropy ranges of $\mathrm{Kv}=\mathrm{Kh} / 10$ (Maréchal et al. 2004).

Model parameter sensitivity analysis using the parameter estimation code PEST (Doherty 1994) was initially conducted for 10 aquifer related parameters (section S10 and Fig. S10 of the ESM). The pilot point calibration approach (Doherty 2003) was used to spatially vary and calibrate the most sensitive parameters; however, due to computational limitations, only the most sensitive parameter, the specific storage of the lower layer, was calibrated using the pilot point approach. Other parameters were included in the calibration, but assuming they were spatially uniform. One of the advantages of the pilot point approach is that it does not require prior definition 
Fig. 3 Conceptual diagram for the precipitation-runoff modelling system (PRMS) (modified from Leavesley et al. 1983)

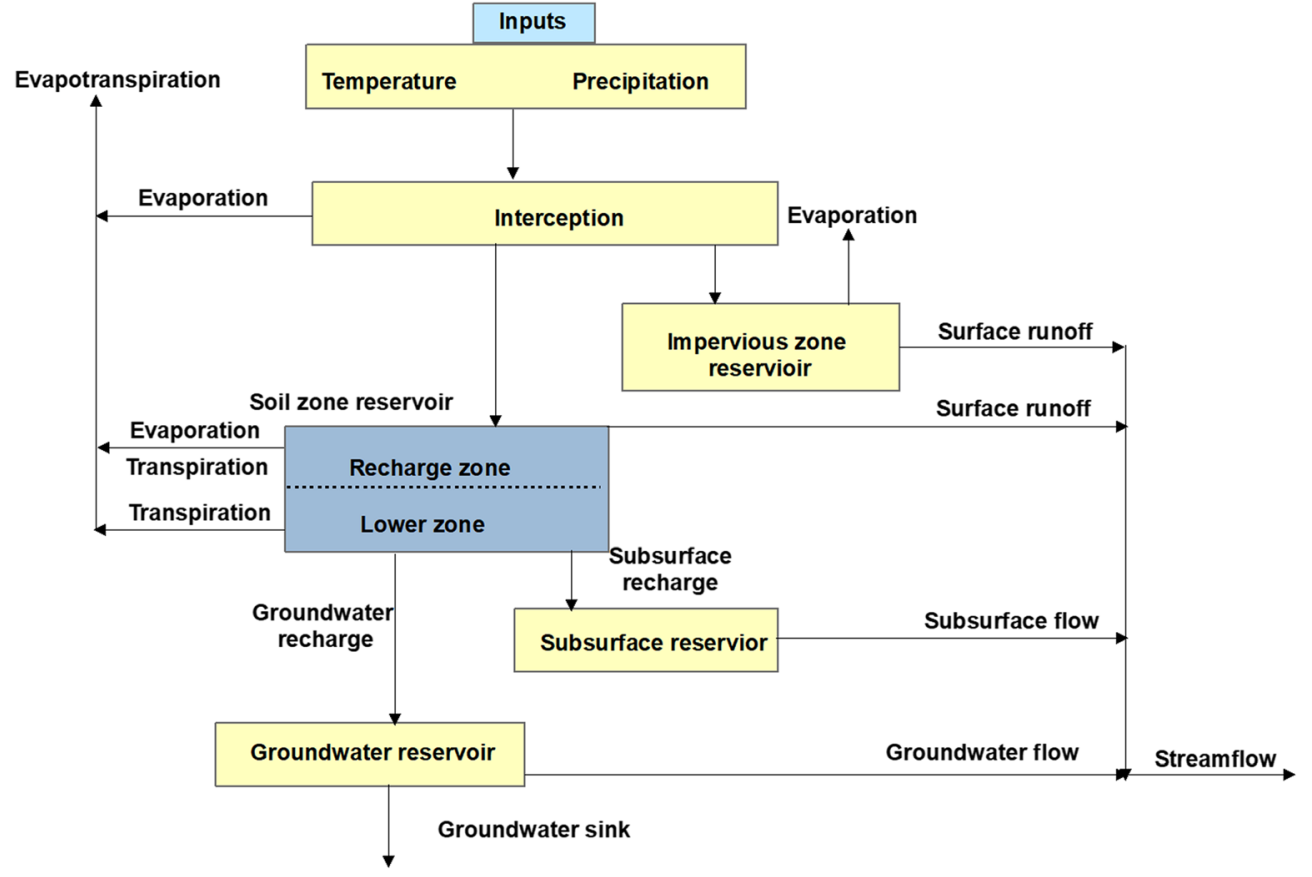

of zonation, rather the calibration process itself decides where heterogeneity exists within the model domain for model outcomes to match measured data. This approach is more likely to approximate geological reality than a distribution based on predetermined zoning of uniform hydraulic property values (Doherty 2003). In the pilot point approach, hydraulic property values are initially assigned to a set of points distributed throughout the model domain and parameter estimation is carried out at the pilot points. Parameter values are then distributed from the pilot points to grid cells through spatial interpolation (kriging).

The calibration was carried out in two steps-(1) the fraction of precipitation that becomes surface runoff $\left(\mathrm{IE}_{\mathrm{SWP}}\right)$ was adjusted using manual calibration by comparing the surface runoff from the MODFLOW-OWHM with runoff estimated using the calibrated PRMS for the Hout sub-catchment of the Sand catchment; (2) assuming the manually calibrated IE $\mathrm{SWP}_{\mathrm{SW}}$ is fixed, automated calibration was performed using PEST. In total, 38 parameters were calibrated (Table S7 of the ESM). The adjustable parameters were horizontal hydraulic conductivity in layer 1 (upper layer) $\left(\mathrm{Kh}_{1}\right)$ and layer 2 (lower layer) $\left(\mathrm{Kh}_{2}\right)$, vertical hydraulic conductivity in layer $1\left(\mathrm{Kv}_{1}\right)$ and layer $2\left(\mathrm{Kv}_{2}\right)$, specific yield in layer $1\left(\mathrm{Sy}_{1}\right)$, specific yield in layer $2\left(\mathrm{Sy}_{2}\right), 24$ pilot points for specific storage in layer 2 $\left(\mathrm{Ss}_{2}\right)$, horizontal anisotropy in layer $1\left(\mathrm{Hani}_{1}\right)$ and layer 2 ( $\left.\mathrm{Hani}_{2}\right)$, GHB conductance $\left(\mathrm{GHB}_{\text {cond }}\right)$ and hydraulic characteristic of dikes $\left(\right.$ Dike $_{\text {hydr }}$ ), streambed vertical hydraulic conductivity for stream segments 1,2 and $4\left(\mathrm{kvr}_{124}\right)$, and for 3 and $5\left(\mathrm{kvr}_{35}\right)$, Manning roughness coefficient for stream segments 1,2 and $4\left(\mathrm{n}_{124}\right)$, and for stream segments 3 and $5\left(\mathrm{n}_{35}\right)$. The location of the 24 pilot points used for calibration of specific storage and final values are shown in Fig. S11 of the ESM. Overall, good measure of fit of observed and simulated water levels was achieved (data not shown); however, in most cases, the simulated water levels were too high. Therefore, in the second step, the $\mathrm{IE}_{\mathrm{SWP}}$ value was adjusted iteratively within the range of Hanson et al. (2015) reported values in order to obtain better measure of fit to water levels. This also accounted partially for constant losses through evaporation from dams and farm ponds, which were not considered in the first step.

\section{Results}

\section{PRMS calibration and validation}

The Nash-Sutcliff efficiency (NSE) between the observed and simulated streamflow during the calibration and validation period were 0.72 and 0.53 , respectively; Fig. 4 shows the observed and simulated monthly streamflow hydrograph for the calibration and validation period. Parameter ranges and calibrated values are presented in Table S6 of the ESM. In general, there is a good correlation between the observed and simulated hydrographs; however, it seems that the model underestimates the peak flows particularly during the validation period, in particular, year 2014 and 2015. The MannKendall trend test of observed annual streamflow during the simulation period shows statistically significant increasing trend $(\alpha<0.05)$. Paradoxically, there is no significant trend of annual observed rainfall across the rainfall stations. Surface sealing and crusting of bare soils and soil compaction 


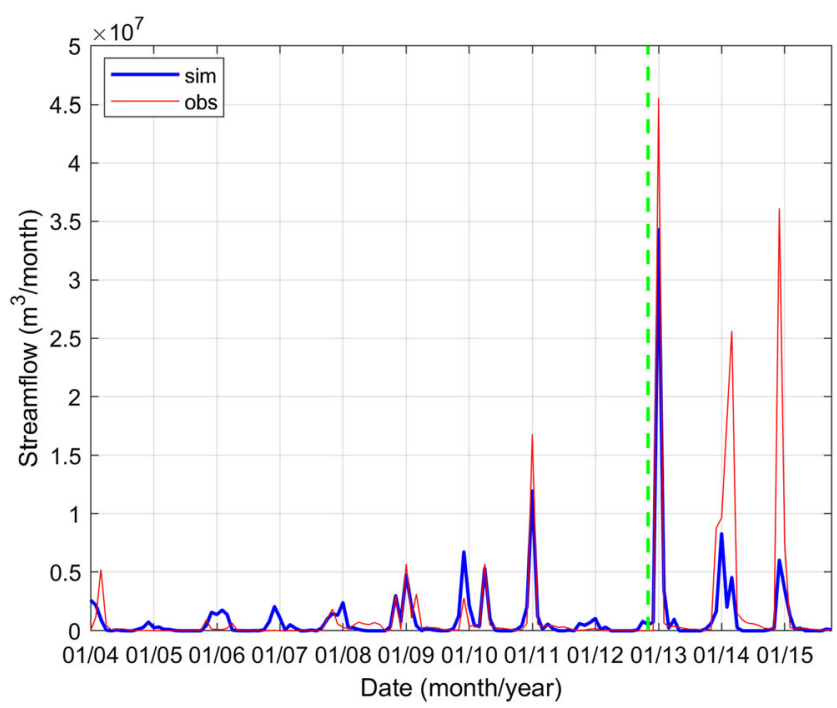

Fig. 4 Observed and simulated monthly streamflow hydrographs for the Sand catchment (vertical green dotted line separates the calibration and validation period)

over time by grazing in rangelands and pasture could reduce soil infiltration capacity and could result in increase in runoff. Land clearing in the upper Sand catchment has been raised as an issue (Wimpie van der Merwe, Soetdoring Groente, personal communication, 2017). Inadequate or decreasing spatial density of rainfall gauges may also result in increasing uncertainty in streamflow simulation. As noted in Henn et al. (2015), this problem is more pronounced in mountainous regions due to the greater spatial variability of orographic precipitation and the general lack of meteorological stations at higher elevations. Further research is needed to understand the cause of increasing trend in streamflow in the Sand catchment.

\section{MODFLOW-OWHM calibration and validation}

In general, good agreements between simulated and observed groundwater levels in layer 2 were obtained (Fig. 5), and the residuals are randomly distributed across the catchment (not shown) in agreement with recommendations by Hill (1998). The specified likely parameter range and final calibrated values are presented in Table S7 of the ESM. The mean absolute error (MAE) and root mean square error (RMSE) between the observed and simulated water levels for the calibration period were 2.04 and $2.54 \mathrm{~m}$, respectively. During the validation period, MAE and RMSE were 3.00 and $4.05 \mathrm{~m}$, respectively. Figure 5 shows the observed and simulated water levels for four selected wells, and Table S8 of the ESM presents the MAE and RMSE for the same wells during the calibration and validation periods. These wells were selected due to their continuous and long-term observation records. In general, the model agreement with observations compares well with other related studies applying hydrogeological models, where there is significant water level difference in the model domain (Tiedeman et al. 2003; Jagelke and Barthel 2005; Cao et al. 2013). Lack of some dynamics in simulated water levels could be due to lack of capture of recharge effects of large short-term precipitation events due to monthly inputs, and local effects or heterogeneities in the aquifer, which are not captured by the model. This includes heterogeneity in hydraulic properties and the specific effects of dikes, as well as focused recharge from depression storage features and farm ponds.

\section{Water budget analysis}

Water budget analysis for the entire model domain (Hout catchment) was carried out using ZONEBUDGET (Harbaugh 2009). The annual water budget of the model domain, consisting of the root zone, the groundwater component and the river system, for 2008-2015 hydrologic years (October-September), is presented in Table 2. The mean annual water budget is presented schematically in Fig. 6. The mean annual simulated evapotranspiration is about $91.9 \%$ of the mean annual rainfall over the study area, while the diffuse recharge and the mean surface runoff accounts for 3.3 and $4.4 \%$ of the annual rainfall, respectively. The river is losing overall, with a mean net flux from the river to the aquifer (focused recharge) of $4.7 \pm 1.7 \mathrm{~mm} /$ year, or $1.1 \%$ of annual rainfall. Irrigation return flows are also small, $1.0 \mathrm{~mm} /$ year or $0.2 \%$ of annual rainfall, indicating that these flows are limited and with only local impact.

Estimated diffuse recharge rates during the simulation period range from 1.3 to $44.5 \mathrm{~mm} /$ year (a mean of $15.9 \pm$ $15.7 \mathrm{~mm} /$ year, or of $3.3 \pm 2.5 \%$ of annual rainfall). Recharge rate varies considerably between wet and dry years. As an example, during the dry hydrologic year of 2011/2012, abstraction exceeded recharge and groundwater storage decreased, while this was reversed during the subsequent wet hydrologic year. Abstraction was significantly negatively correlated with rainfall $\left(R^{2}=0.87\right)$, indicating the indirect anthropogenic impact of drought on groundwater storage.

Evapotranspiration directly from groundwater is a significant component of the groundwater budget of the study area, accounting for $6.9 \mathrm{~mm} /$ year $\left(17.0 \times 10^{6} \mathrm{~m}^{3} /\right.$ year $)$, which is about $43.1 \%$ of the recharge. To verify the significance of the evapotranspiration from groundwater, the area subjected to evapotranspiration from groundwater was calculated for 1 month during the validation period (Feb 2015; section S12 of the ESM) and found to be 4,405 ha (1.8\% of the catchment area). Evapotranspiration from groundwater mainly occurs along the river downstream of the Hout River Dam (Fig. S12 of the ESM), which is a temporal wetland. In comparison, the mean irrigated area during the simulation period for the dry and wet periods are 2,339 and 2,225 ha (0.9\% of the catchment area), respectively (Table S4 of the ESM). This 


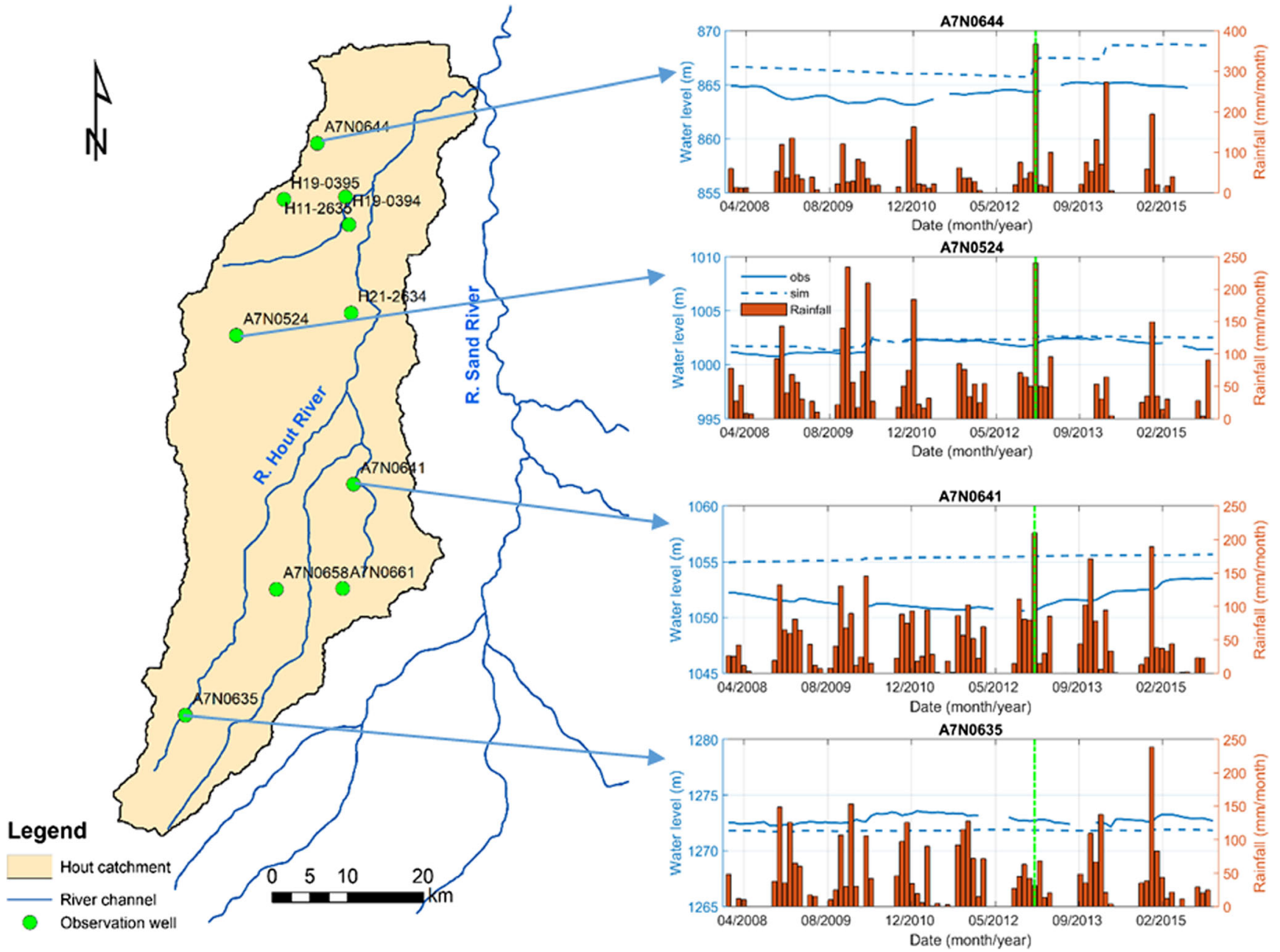

Fig. 5 Observed and simulated groundwater levels during the calibration and validation period for four monitoring wells (vertical green lines in the rightside time series plots separate the calibration and validation period)

indicates that, although, evapotranspiration from groundwater may vary from stress period to stress period, the groundwater evapotranspiration area is roughly 0.97 times the total irrigated area, hence this component is significant to the overall water balance. After groundwater evapotranspiration, the second largest discharge component of the groundwater budget is irrigation abstraction $(6.9 \pm 0.9 \mathrm{~mm} /$ year $)$.

Recharge simulated by the PRMS model ranges from 0 to $106.6 \mathrm{~mm} /$ year. The mean simulated recharge by PRMS is $39.0 \pm 38.0 \mathrm{~mm} /$ year, and compares reasonably well with MODFLOW-OWHM results (Table 1), within $R^{2}=0.62$. The mean simulated evapotranspiration by the PRMS model is $305.2 \pm 70.5 \mathrm{~mm} /$ year, while MODFLOW-OWHM simulated evapotranspiration is $394.2 \pm 86.1 \mathrm{~mm} /$ year. There is good correlation between the simulated evapotranspiration $\left(R^{2}=0.78\right)$; however, the simulated mean evapotranspiration by the PRMS model is lower than the MODFLOW-OWHM. The mean streamflow stimulated by PRMS is $2.2 \pm 1.5 \mathrm{~mm} /$ year, while that of MODFLOW-OWHM is $14.3 \pm 15.4 \mathrm{~mm} /$ year. The correlation between the simulated runoff in the two models is reasonably good $\left(R^{2}=0.71\right)$. The main reasons for higher simulated streamflow by MODFLOW-OWHM could be due to lack of accounting for soil moisture change and lack of representation of surface depression storage to account for part of the surface runoff that is detained in the dam and small farm ponds. MODFLOW-OWHM assumes steady-state soilmoisture storage within each time step. Recent studies by Dahlke et al. (2018) showed that for well-managed irrigated soils, change in soil-moisture storage is small; however, for native vegetation and dry-land farming, the assumption of steady state soil-moisture storage may result in poor approximation (Hanson et al. 2010). In natural vegetation and dry land farming settings, ignoring soil-moisture storage change may result in underestimation of ET due to lack of carry-over of water storage in the root zone from one time step to the next. According to Hudson (1988), for average rainfall years, soilmoisture storage change can be ignored in annual water budget calculations; however, ignoring soil-moisture storage change in catchment water budgets during extreme years (wet or dry) could have significant impact on catchment water balance. 
Table 2 Annual and mean annual simulated water budget (mm/year) for the Hout catchment for the hydrologic years of 2008-2015. SD standard deviation

\begin{tabular}{|c|c|c|c|c|c|c|c|c|c|}
\hline Hydrologic Year & $\begin{array}{l}2008 / \\
2009\end{array}$ & $\begin{array}{l}2009 / \\
2010\end{array}$ & $\begin{array}{l}2010 / \\
2011\end{array}$ & $\begin{array}{l}2011 / \\
2012\end{array}$ & $\begin{array}{l}2012 / \\
2013\end{array}$ & $\begin{array}{l}2013 / \\
2014\end{array}$ & $\begin{array}{l}2014 / \\
2015\end{array}$ & Mean & $\mathrm{SD}( \pm)$ \\
\hline Rainfall & 478.2 & 607.7 & 394.9 & 329.7 & 528.2 & 320.9 & 344.4 & 429.2 & 111.1 \\
\hline Evapotranspiration & 463.4 & 513.3 & 378.4 & 325.3 & 464.8 & 293.1 & 321.6 & 394.2 & 86.1 \\
\hline Surface runoff & 9.1 & 49.9 & 9.3 & 3.1 & 32.9 & 15.3 & 13.1 & 19.0 & 16.5 \\
\hline Diffuse recharge & 5.8 & 44.5 & 7.3 & 1.3 & 30.6 & 12.4 & 9.7 & 15.9 & 15.7 \\
\hline Irrigation return flow & 0.9 & 0.8 & 1.2 & 1.1 & 0.9 & 1.1 & 1.1 & 1.0 & 0.1 \\
\hline $\begin{array}{l}\text { Net flux from the river to the aquifer } \\
\text { (equals focused recharge if positive) }\end{array}$ & 5.2 & 8.1 & 5.0 & 3.1 & 3.7 & 4.8 & 2.9 & 4.7 & 1.7 \\
\hline Streamflow & 3.9 & 41.9 & 4.3 & 0.0 & 29.1 & 10.5 & 10.2 & 14.3 & 15.4 \\
\hline Domestic use and stock watering & 1.8 & 1.8 & 1.8 & 1.8 & 1.8 & 1.8 & 1.8 & 1.8 & 0.0 \\
\hline Total irrigation pumping & 6.1 & 5.6 & 7.8 & 7.5 & 6.2 & 7.6 & 7.4 & 6.9 & 0.9 \\
\hline Net lateral flux out of the aquifer & 0.9 & 0.6 & 0.6 & 1.1 & 0.6 & 0.1 & 0.7 & 0.7 & 0.3 \\
\hline Evapotranspiration from groundwater & 6.2 & 6.5 & 6.9 & 6.8 & 6.5 & 6.1 & 5.8 & 6.4 & 0.4 \\
\hline Groundwater storage change & -3.0 & 38.9 & -3.7 & -11.6 & 20.1 & 2.9 & -1.9 & 6.0 & 17.5 \\
\hline Recharge as a percentage of annual rainfall & 1.2 & 7.3 & 1.8 & 0.4 & 5.8 & 3.9 & 2.8 & 3.3 & 2.5 \\
\hline PRMS evapotranspiration & 343.7 & 419.2 & 259.2 & 228.3 & 356.3 & 291.9 & 238.2 & 305.2 & 70.5 \\
\hline PRMS simulated streamflow & 1.4 & 3.8 & 2.4 & 0.4 & 4.7 & 1.1 & 1.8 & 2.2 & 1.5 \\
\hline PRMS simulated recharge & 9.5 & 68.7 & 47.9 & 0.0 & 106.6 & 16.6 & 23.9 & 39.0 & 38.0 \\
\hline
\end{tabular}

\section{Discussion}

Previous studies did not capture temporal (annual to decadal) variability in recharge and groundwater storage during wet and dry periods in the area. Vegter (1995) estimated recharge in the Mogwadi area to $8 \mathrm{~mm} /$ year on the basis of the effective rainfall concept; however, previously, Vegter (1992) estimated a recharge of $23.6 \mathrm{~mm} / \mathrm{year}$ for Alldays, a town close to Mogwadi. According to Vegter (1992), the reason for the wide-ranging estimates is the difference in transpiration losses between shallow-rooted Karoo and deeper-rooted Bushveld vegetation. Holland (2011) estimated recharge in the Mogwadi area using the chloride mass balance method to be
$2 \mathrm{~mm} /$ year. In comparison, this study found diffuse recharge to vary from 1.3 to $44.5 \mathrm{~mm} /$ year, with a mean of $15.9 \pm$ $15.7 \mathrm{~mm} /$ year. Annual recharge as a fraction of rainfall had a mean and standard deviation of $3.3 \pm 2.5 \%$. Both absolute and relative estimates for annual recharge confirm that recharge is highly variable (Xu and Beekman 2003) and not an approximate constant annual figure, not even a constant fraction of rainfall under these conditions (this study found the correlation $\left(R^{2}\right)$ between recharge and rainfall to be 0.34 ), which has previously been put forward (DWAF 2006). Long-term historical data from few monitoring wells in the hard rock formations (including well A7N0524 also shown in Fig. 7) indicate large decadal fluctuations in groundwater levels,
Fig. 6 Mean annual water budget for hydrologic years 2008-2015 $(\mathrm{mm} /$ year)

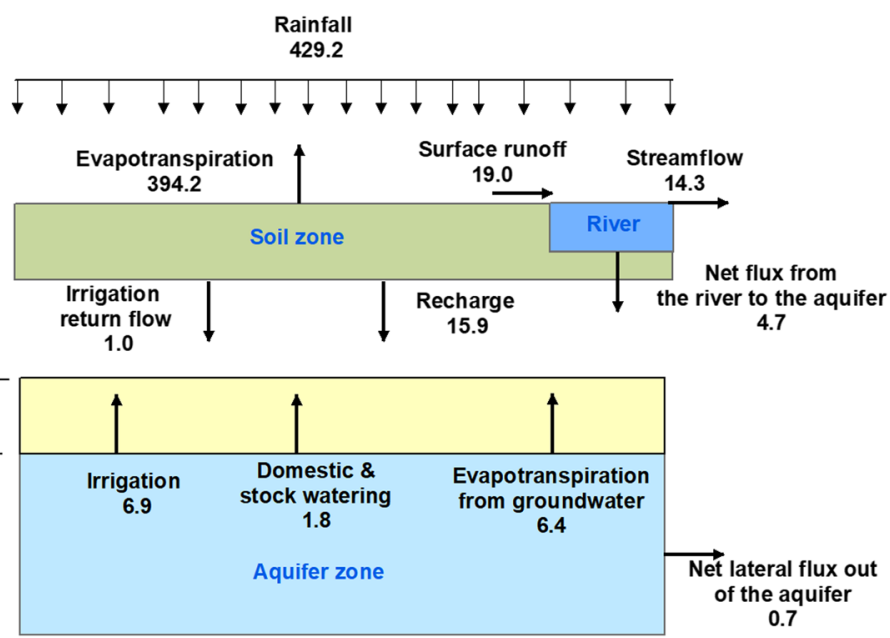




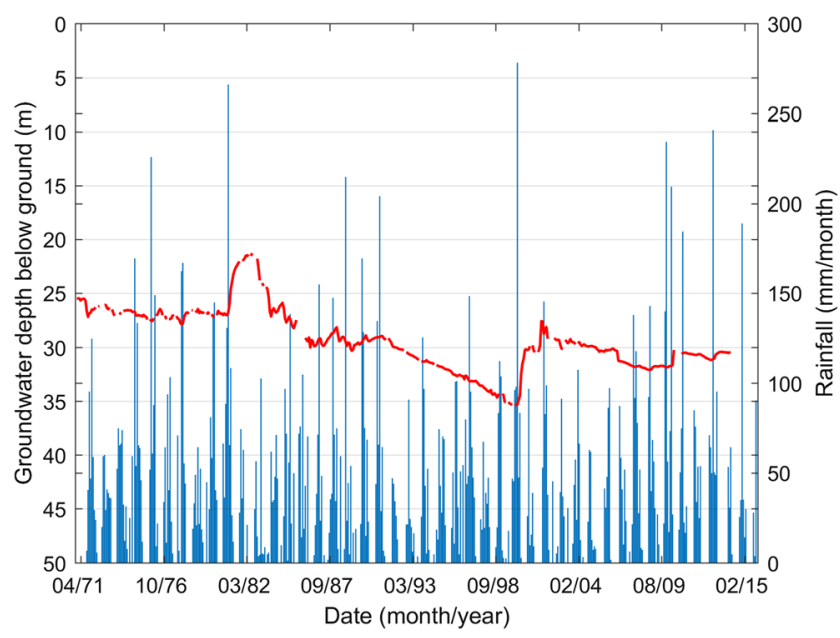

Fig. 7 Historical water level in A7N0524 monitoring well and rainfall data since early 1970s. In the period between 1990 and 2000, the water level in this well showed a steady decline (about $6 \mathrm{~m}$ decline during this period). This persistent, multiyear decline in groundwater level is an indication that the level of pumping is not sustainable

reflecting shifts between periods of mostly negative accumulation of groundwater storage due to below-average precipitation and/or continuous or increasingly high abstraction rates, and infrequent periods of significant positive accumulation, influenced by short-term recharge events in response to larger rainfall/flooding events (e.g. in 2000, Fig. S7 of the ESM). During the simulation period, the groundwater storage change component had a mean and standard deviation of $6.0 \pm$ $17.5 \mathrm{~mm} /$ year, indicating the highly dynamic accumulated effect of variable recharge and abstraction. From Fig. 5, it is seen that the high rainfall years (2009-2010 and 2012-2013) gave rise to most noticeable increases in groundwater levels. Unfortunately, a longer simulation period, enabling the simulation of more extreme years, was not possible due to lack of long-term historic water level data. A mean actually irrigated area of $0.9 \%$ of the catchment area (irrigated during both wet and dry seasons) appears to be sustainable over the simulated period, as seen from long-term semi-stable groundwater levels and slight positive increase in groundwater storage, indicating a limited potential for irrigation expansion under given cropping and climate conditions. These average values, may however, mask local effects of over-abstraction, which were not analysed. The results are critical findings because recharge, as a relatively small but highly variable component of the water balance, is greatly important to the livelihoods and economics of the area.

Variability and trends over the years in recharge, as affected by climatic variability, may impact negatively on the sustainability of the coupled human and natural system, indicating vulnerability of areas like Hout. This vulnerability is exacerbated by climate change and increasing human dependence on groundwater, illustrating the critical need for sound management of the resource, e.g. through proper land use management, irrigation planning, climate forecasting (Fallon et al. 2018), and careful attention to water quality as well as development of additional/alternative water sources, e.g. through proper treatment and recycling of wastewater.

The mean annual simulated irrigation pumping for the period 2008-2015 was $6.9 \mathrm{~mm} /$ year $\left(17.0 \times 10^{6} \mathrm{~m}^{3} /\right.$ year $)$. The mean annual irrigation licensed volume (aggregated for all licensed farmers) for the same period, as obtained from DWS, was $11.3 \mathrm{~mm} /$ year $\left(28.0 \times 10^{6} \mathrm{~m}^{3} /\right.$ year $)$. This analysis shows that the licensed volume is almost twice the actual irrigation pumping calculated based on the optimal crop water requirements. The possible explanation for the two could be that farmers are abstracting less than their allotted amounts because of some constraints, or it could be that farmers were licensed more than what they need presently, in order to secure water for future agricultural expansion. If the first is the case and farmers pump less because of physical, chemical, or economic constraints in terms of accessing groundwater (Wimpie van der Merwe, Soetdoring Groente, personal communication, 2017), it indicates that licensed volumes are likely exaggerated in terms of what the aquifer can provide sustainably, even today. It is important to note that the irrigation pumping estimated in this study is conservative (i.e. on the high side) as it assumes groundwater-pumping equivalent to optimal crop irrigation requirements, which may not hold.

Integrated hydrogeological models are useful for analysing complex water resources problems (Refsgaard and Storm 1995), but their trustworthiness strongly depends on the reliability and density of spatial and temporal data. The known sources of uncertainty in the present analysis are: (1) estimation of cropping area and their temporal and spatial variability using NDVI; (2) lack of observation well data across spatial and temporal scales for model calibration and validation; (3) lack of streamflow data and groundwater level data close to the river, which would help to better constrain streamflow routing and estimation of focused recharge from the river; (4) local scale heterogeneities that cannot be simulated using the EPM approach (Scanlon et al. 2003), e.g. the role of enhanced fracture zones associated to dike intrusions; (5) the impact of the Hout River Dam and small farm ponds; (6) short-term or episodic processes not represented due to the monthly stress period applied, and (7) lack of representation of soil-moisture storage change in the model. Regarding point 6 , it is interesting to note that 2009-2010 was more extreme in terms of total rainfall $(781 \mathrm{~mm})$ compared to $1999-2000$ $(700 \mathrm{~mm})$; yet the annual groundwater level increase in 2009-2010 in response to the wet season was less pronounced than that of 1999-2000 (Fig. 7). This may be explained by the difference in short term (daily) rainfall intensity, where this was higher in 1999-2000 than in 2009-2010 (data not shown). It has been shown that short-term intensive rainfall in arid areas can generate significant and higher than proportionally higher recharge relative to rainfall (Ahmed et al. 
2008). Regarding point 7 , it is important to note that due to approximation of steady-state soil-moisture storage in the root zone for nonirrigated areas (mainly natural vegetation), the MODFLOW-OWHM model over-simulated streamflow. This may have little impact on simulated irrigation pumping and recharge, because, soil moisture variation in irrigated areas is expected to be small and recharge was constrained based on observed groundwater level data. However, to better simulate water resources in the catchment, especially streamflow, it is important to include soil-moisture storage change in the analysis.

\section{Conclusions}

To support the understanding of the hard rock aquifer system and to provide baseline information about the recharge, water balances, and aquifer dynamics in the Hout catchment to inform management, an integrated modelling approach including a 3D dynamic integrated hydrogeological model was developed and calibrated to observed groundwater level data and river discharge in the larger Sand catchment encompassing the Hout catchment. The calibrated model was used to compute an annual water budget for the hydrological system over the seven hydrologic years in simulation period 2008-2015. The results of the transient simulation indicate that diffuse groundwater recharge is a small component of the water balance (3.3 $\pm 2.5 \%$ of annual rainfall), while associated with high temporal variability, mainly due to variability in rainfall and groundwater abstraction. The estimated mean diffuse recharge during the simulation period was $15.9 \pm 15.7 \mathrm{~mm} /$ year, and the mean groundwater storage change was $6.0 \pm 17.5 \mathrm{~mm} /$ year. This reflects a human-natural system with high dependence on a highly variable resource, vulnerable to potential long-term negative recharge change trends due to climate change and increased dependence on the resource, despite a potential trend in climate-change-induced increasing risk of extreme rainfall events, which could enhance recharge, implying the need for pro-active groundwater management.

With regard to the licensing, farmers are abstracting less than their allotted amount. This is likely due to constraints faced in terms of accessing reliable and good quality groundwater, rather than choice, and illustrates that licensing could have been done based on overly positive assumptions of groundwater availability. Irrigation from only $0.9 \%$ of the catchment area appears close to the sustainability limit under present conditions. Interestingly, natural direct evapotranspiration from groundwater from a local wetland was found to be the main water discharge component of the groundwater system. Further research is recommended to investigate local processes controlling focused recharge and the impact of episodic precipitation and flooding events on recharge. In general, the modelling approach proved to be useful, and the methodology is suitable to irrigated hard rock areas in semiarid and arid areas, where hitherto relatively limited integrated dynamic modelling has been conducted (Dewandel et al. 2006).

In order to further apply the model in a management context, it is crucial to sustain and expand groundwater, rainfall and streamflow monitoring, with a focus on broad coverage of the catchment as well as more intense monitoring in hotspot (intensive abstraction) areas and close to the stream. It is critical to further assess the sensitivity of recharge and groundwater storage to various scenarios of climate change and future changes in land use and groundwater abstraction. With improved data coverage and simple seasonal climate forecasting (Fallon et al. 2018), the model could be applied in a near real-time mode, as a means to supporting irrigation and cropping planning. Water quality aspects also need to be addressed going forward.

The methodology developed in this study is applicable to irrigated areas in semi-arid regions. Of particular interest is the use of remote sensing data, in particular to provide timely information on often lacking data on irrigated area and agricultural water use over large areas.

Acknowledgements The authors would like to thank Department of Water and Sanitation, South Africa, for providing data on groundwater levels and streamflow. Rainfall data were kindly provided by South Africa Weather Service. We are also very grateful to Mr. Heyns Verster for his support in data collection and for discussions during the research. We thank Dr. Richard B Winston, Dr. Randy Hanson and Dr. Scott E. Boyce from USGS for their help with the modelling.

Funding information The authors acknowledge the financial support provided by GroFutures - the Groundwater Futures in Sub-Saharan Africa project, funded by the Natural Environment Research Council (NERC) and the Economic and Social Research Council (ESRC) (UPGro No. NE/M008932/1), the CGIAR Research Program on Water, Land and Ecosystems (WLE), and the Groundwater Recharge in the Limpopo River Basin (GRECHLIM) project, funded by United States Agency for International Development (USAID-Southern Africa, AIDOAA-A-11-00012) and National Research Foundation (NRF), South Africa. The work was undertaken in collaboration with the Chronicles Consortium (IGRAC 2018), supported by the UK government under the UPGro programme.

Open Access This article is distributed under the terms of the Creative Commons Attribution 4.0 International License (http:// creativecommons.org/licenses/by/4.0/), which permits unrestricted use, distribution, and reproduction in any medium, provided you give appropriate credit to the original author(s) and the source, provide a link to the Creative Commons license, and indicate if changes were made.

\section{References}

Abbott M, Bathurst J, Cunge J, O'connell P, Rasmussen J (1986a) An introduction to the European Hydrological System-Systeme Hydrologique Europeen, "SHE", 2: structure of a physically-based, distributed modelling system. J Hydrol 87:61-77 
Abbott M, Bathurst J, Cunge J, O’Connell P, Rasmussen J (1986b) An introduction to the European hydrological system, SHE. 1: history and philosophy of a physically based, distributed modelling system. J Hydrol 87:45-59

Ahmed S, Maréchal J, Ledoux E, de Marsily G (2008) Groundwater flow modelling in hard-rock terrain in semi-arid areas: experience from India. In: Hydrological modelling in arid and semi-arid areas. Cambridge University Press, Cambridge, UK, pp 157-190

Allen R, Pereira L, Raes D, Smith M (1998) Crop evapotranspirationguidelines for computing crop water requirements. FAO irrigation and drainage paper 56. FAO, Rome 300:D05109

Arcement G, Schneider V (1989) Guide for selecting Manning's roughness coefficients for natural channels and flood plains. US Government Printing Office, Washington, DC

Barlow P, Dickerman D (2001) Numerical-simulation and conjunctivemanagement models of the Hunt-Annaquatucket-Pettaquamscutt stream-aquifer system, Rhode Island. US Geol Surv Prof Pap 1636

Bromley J, Mannström B, Nisca D, Jamtlid A (1994) Airborne geophysics: application to a ground-water study in Botswana. Ground Water 32:79-90

Bushira KM, Hernandez JR, Sheng Z (2017) Surface and groundwater flow modeling for calibrating steady state using MODFLOW in Colorado River Delta, Baja California, Mexico. Model Earth Syst Environ 3:815-824

Cao G, Zheng C, Scanlon B, Liu J, Li W (2013) Use of flow modeling to assess sustainability of groundwater resources in the North China plain. Water Resour Res 49:159-175

DAFF (2013) Potatoes: production guideline. In: Department of Agriculture $\mathrm{FaF}$ (ed) Directorate plant production, division: vegetables. DAFF, Pretoria, South Africa

Dahlke H, Brown A, Orloff S, Putnam D, O'Geen T (2018) Managed winter flooding of alfalfa recharges groundwater with minimal crop damage. Cal Agric 72:65-75

Dewandel B, Lachassagne P, Wyns R, Maréchal J, Krishnamurthy N (2006) A generalized 3-D geological and hydrogeological conceptual model of granite aquifers controlled by single or multiphase weathering. J Hydrol 330:260-284

Dogrul E, Brush C, Kadir T (2016) Groundwater modeling in support of water resources management and planning under complex climate, regulatory, and economic stresses. Water 8:592

Doherty J (1994) PEST: a unique computer program for modelindependent parameter optimisation. Groundwater/surface hydrology common interest papers; preprints of papers. Water Down Under 94, 22nd Hydrology and Water Resources Symposium, Adelaide, Australia, November 1994, $551 \mathrm{pp}$

Doherty J (2003) Ground water model calibration using pilot points and regularization. Groundwater 41:170-177

du Toit W (2001) An investigation into the occurrence of groundwater in the contact aureole of large granite intrusions (batholiths) located west and northwest of Pietersburg, vol 1, Dept. of Water Affairs and Forestry, Pretoria, South Africa

DWAF (2006) Groundwater resources assessment II: task 3aE recharge, final report. Department of Water Affairs and Forestry, Pretoria, South Africa, $129 \mathrm{pp}$

Fallon A, Villholth K, Conway D, Lankford B, Ebrahim G (2018) Agricultural groundwater management strategies and seasonal climate forecasting: perceptions from Mogwadi (Dendron), Limpopo, South Africa. J Water Climate Change jwc2018042. https://doi.org/ $10.2166 /$ wcc. 2018.042

FAO (2004) Drought impact mitigation and prevention in the Limpopo River Basin: a situation analysis. FAO Sub-Regional Office, Harare, Zimbabwe

Faunt C (2009) Groundwater availability of the Central Valley aquifer, California. US Geological Survey, Reston, VA

Faunt C, Blainey J, Hill M, D'Agnese F, O'Brien G (2004) Transient numerical model: Death Valley regional ground-water flow system,
Nevada and California-hydrologic framework and transient ground-water flow model. US Geol Surv Sci Invest Rep 5205: 257-352

Franke A, Haverkort A, Steyn J (2013) Climate change and potato production in contrasting south African agro-ecosystems: 2. assessing risks and opportunities of adaptation strategies. Potato Res 56:51-66

Ghasemizadeh R, Yu X, Butscher C, Hellweger F, Padilla I, Alshawabkeh A (2015) Equivalent porous media (EPM) simulation of groundwater hydraulics and contaminant transport in karst aquifers. PLoS One 10:e0138954

Hanson R, Schmid W, Faunt C, Lockwood B (2010) Simulation and analysis of conjunctive use with MODFLOW's farm process. Ground Water 48:674-689

Hanson R, Schmid W, Faunt C, Lear J, Lockwood B (2014a) Integrated hydrologic model of Pajaro Valley, Santa Cruz and Monterey counties, California. US Geol Surv Sci Invest Rep 2014-5111

Hanson R, Boyce S, Schmid W, Hughes J, Mehl S, Leake S, Maddock III T, Niswonger R (2014b) One-Water Hydrologic Flow Model (MODFLOW-OWHM). US Geol Surv Techniques Methods 6-A51

Hanson R, Flint L, Faunt C, Gibbs D, Schmid W (2015) Hydrologic models and analysis of water availability in Cuyama Valley, California. UUS Geol Surv Sci Invest Rep 2014-5150

Harbaugh A (2005) MODFLOW-2005, the US geological survey modular ground-water model: the ground-water flow process. US Geological Survey, Reston

Harbaugh A (2009) Zonebudget version 3.01, a computer program for computing subregional water budgets for MODFLOW groundwater flow models. US Geological Survey Groundwater Software. https://water.usgs.gov/nrp/gwsoftware/zonebud3/zonebudget3. html. Accessed March 2019

Hargreaves GH, Samani ZA (1985) Reference crop evapotranspiration from temperature. Appl Eng Agric 1:96-99

Hassan S, Lubczynski M, Niswonger R, Su Z (2014) Surfacegroundwater interactions in hard rocks in Sardon catchment of western Spain: an integrated modeling approach. J Hydrol 517:390-410

Hay L, Leavesley G, Clark M, Markstrom S, Viger R, Umemoto M (2006) Step wise multiple objective calibration of a hydrologic model for a snowmelt dominated basin. J Am Water Resour Assoc 42: 877-890

Henn B, Clark M, Kavetski D, Lundquist J (2015) Estimating mountain basin-mean precipitation from streamflow using Bayesian inference. Water Resour Res 51:8012-8033

Hill M (1998) Methods and guidelines for effective model calibration. US Geol Surv Water Resour Sci Invest Rep 98-4005

Holland M (2011) Hydrogeological characterisation of crystalline basement aquifers within the Limpopo Province, South Africa. PhD Thesis, University of Pretoria, South Africa

Holland M (2012) Evaluation of factors influencing transmissivity in fractured hard-rock aquifers of the Limpopo Province. Water SA 38:379-390

Holland M, Witthüser K (2011) Evaluation of geologic and geomorphologic influences on borehole productivity in crystalline bedrock aquifers of Limpopo Province, South Africa. Hydrogeol J 19:1065-1083

Howell T (2003) Irrigation efficiency. In: Encyclopedia of water science. Dekker, New York, pp 467-472

Hsieh P, Freckleton J (1993) Documentation of a computer program to simulate horizontal-flow barriers using the US Geological Survey's modular three-dimensional finite-difference ground-water flow model. US Geol Surv Open-File Rep 92-477

Hudson J (1988) The contribution of soil moisture storage to the water balances of upland forested and grassland catchments. Hydrol Sci J 33:289-309

IGRAC (2018) The chronicles consortium. https://www.un-igrac.org/ special-project/chronicles-consortium. Accessed March 2018 
Jagelke J, Barthel R (2005) Conceptualization and implementation of a regional groundwater model for the Neckar catchment in the framework of an integrated regional model. Adv Geosci 5:105-111

Jolly J (1986) Borehole/irrigation survey and ground-water evaluation of the Doringlaagte Drainage Basin Dendron directorate: geohydrology. GH Report no. 3495, Department of Water Affairs, Pretoria, South Africa

Kaehler C, Hsieh P (1994) Hydraulic properties of a fractured-rock aquifer, Lee Valley, San Diego County, California. US Geol Surv Open file Rep 90-592

Kim N, Chung I, Won Y, Arnold J (2008) Development and application of the integrated SWAT-MODFLOW model. J Hydrol 356:1-16

Larocque M, Banton O, Ackerer P, Razack M (1999) Determining karst transmissivities with inverse modeling and an equivalent porous media. Ground Water 37:897-903

Leavesley G, Lichty R, Troutman B, Saindon L (1983) Precipitationrunoff modeling system: user's manual. US Geological Survey, Washington, DC

Leavesley G, Stannard L, Singh V (1995) The precipitation-runoff modeling system-PRMS, Chap 7. In: Computer models of watershed hydrology. CRC, Boca Raton, FL, pp 281-310

Lombaard J, Sikosana S, Van Niekerk E (2015) The development of the Limpopo Water Management Area North Reconciliation Strategy Hydrological Analysis, vol 2. DWS report no. PWMA 01/000/00/ 02914/3, DWS, Pretoria, South Africa

Long J, Remer J, Wilson C, Witherspoon P (1982) Porous media equivalents for networks of discontinuous fractures. Water Resour Res 18: 645-658

MacDonald A, Calow R, Macdonald D, Darling W, Dochartaigh B (2009) What impact will climate change have on rural groundwater supplies in Africa? Hydrol Sci J 54:690-703

Maréchal J, Dewandel B, Subrahmanyam K (2004) Use of hydraulic tests at different scales to characterize fracture network properties in the weathered-fractured layer of a hard rock aquifer. Water Resour Res 40(11). https://doi.org/10.1029/2004WR003137

Markstrom S, Niswonger R, Regan R, Prudic D, Barlow P (2008) GSFLOW-coupled ground-water and surface-water FLOW model based on the integration of the precipitation-runoff modeling system (PRMS) and the modular ground-water flow model (MODFLOW2005). US Geol Surv Techniques Methods 6-D1, 240 pp

Morel E, Wikramaratna R (1982) Numerical modelling of groundwater flow in regional aquifers dissected by dykes. Hydrol Sci J 27:63-77

New L, Fipps G (2000) Center pivot irrigation. http:/hdl.handle.net/ $1969.1 / 86877$

NGWA (2017) National Groundwater Associations (NGWA) integrated surface water-groundwater modelling white paper. NGWA, Westerville, $\mathrm{OH}$

Niswonger R, Prudic D (2005) Documentation of the StreamflowRouting (SFR2) package to include unsaturated flow beneath streams: a modification to SFR1. US Geol Surv Techniques Methods 6-A13

Niswonger R, Prudic D, Regan R (2006) Documentation of the unsaturated-zone flow (UZF1) package for modeling unsaturated flow between the land surface and the water table with MODFLOW-2005. US Geol Surv Techniques Methods 6-A19

Ozdogan M, Yang Y, Allez G, Cervantes C (2010) Remote sensing of irrigated agriculture: opportunities and challenges. Remote Sens 2: 2274-2304

Pervez M, Budde M, Rowland J (2014) Mapping irrigated areas in Afghanistan over the past decade using MODIS NDVI. Remote Sens Environ 149:155-165

Qin H, Cao G, Kristensen M, Refsgaard J, Rasmussen M, He X, Liu J, Shu Y, Zheng C (2013) Integrated hydrological modeling of the
North China plain and implications for sustainable water management. Hydrol Earth Syst Sci 17:3759-3778

Refsgaard J, Storm B (1995) MIKE SHE. In: Singh V (ed) Computer models of watershed hydrology. Water Resources, Littleton, CO, pp 809-846

Riskscape (2017) Riskscape. http://riskscape.pro/. Accessed March 2018

Rushton K, Weller J (1985) Response to pumping of a weatheredfractured granite aquifer. J Hydrol 80:299-309

Scanlon B, Mace R, Barrett M, Smith B (2003) Can we simulate regional groundwater flow in a karst system using equivalent porous media models? Case study, Barton Springs Edwards aquifer, USA. J Hydrol 276:137-158

Schmid W (2004) A farm package for MODFLOW-2000: simulation of irrigation demand and conjunctively managed surface-water and ground-water supply. PhD Thesis, University of Arizona, Tempe, AZ

Schmid W, Hanson R (2009) The Farm Process version 2 (FMP2) for MODFLOW-2005: modifications and upgrades to FMP1. US Geol Surv Techniques Methods 6-A32

Schmid W, Hanson R, Maddock III T, Leake S (2006) User guide for the farm process (FMP1) for the US geological Survey's modular threedimensional finite-difference ground-water flow model, MODFLOW-2000. US Geological Survey Techniques Methods 6A17

Shu Y, Villholth K, Jensen K, Stisen S, Lei Y (2012) Integrated hydrological modeling of the North China plain: options for sustainable groundwater use in the alluvial plain of Mt. Taihang. J Hydrol 464: 79-93

Sophocleous M, Perkins S (2000) Methodology and application of combined watershed and ground-water models in Kansas. J Hydrol 236: 185-201

Tiedeman C, Hill M, D’Agnese F, Faunt C (2003) Methods for using groundwater model predictions to guide hydrogeologic data collection, with application to the Death Valley regional groundwater flow system. Water Resour Res 39

Titus R, Beekman H, Adams S, Strachan L (2009) The basement aquifers of southern Africa. Water Research Commission report no. TT 42809, Water Research Commission, Pretoria, South Africa, 183 pp

van der Waals J, Korsten L, Slippers B (2004) Genetic diversity among Alternaria solani isolates from potatoes in South Africa. Plant Dis 88:959-964

Varalakshmi V, Venkateswara Rao B, SuriNaidu L, Tejaswini M (2012) Groundwater flow modeling of a hard rock aquifer: case study. J Hydrol Eng 19:877-886

Vegter J (1992) De Aar's groundwater supply: a digest of the past and an outlook for the future. Tech. Rep. GH 3775, Dept. Water Affairs and Forestry, Pretoria, South Africa

Vegter J (1995) An Explanation of a set of national groundwater maps. Report TT 74/95, Water Research Commission, Pretoria, South Africa

Vegter J (2003) Hydrogeology of groundwater regions, region 7, Polokwane/Pietersburg plateau. WRC report no. TT 209/03. Water Research Commission, Pretoria, South Africa

Villholth K, Tøttrup C, Stendel M, Maherry A (2013) Integrated mapping of groundwater drought risk in the southern African development community (SADC) region. Hydrogeol J 21:863-885

Winston R (2009) ModelMuse: a graphical user interface for MODFLOW-2005 and PHAST, chap 29. In: Modelling techniques, book 6 section A. US Geological Survey, Reston, VA

Xu X, Huang G, Zhan H, Qu Z, Huang Q (2012) Integration of SWAP and MODFLOW-2000 for modeling groundwater dynamics in shallow water table areas. J Hydrol 412:170-181

Xu Y, Beekman H (2003) Groundwater recharge estimation in southern Africa. UNESCO IHP series no. 64, UNESCO, Paris 207 pp 